\title{
LIST APOSTOLSKI BENEDYKTA XVI Z OKAZJI 1600. ROCZNICY ŚMIERCI ŚW. JANA CHRYZOSTOMA*
}

\author{
Czcigodni Bracia w biskupstwie i kapłaństwie, \\ drodzy Bracia i Siostry w Chrystusie!
}

1. Wprowadzenie. W tym roku mija 1600 lat od śmierci św. Jana Chryzostoma, wielkiego Ojca Kościoła, otaczanego czcią przez chrześcijan wszystkich czasów. W starożytnym Kościele św. Jan Chryzostom zasłynął tym, że doprowadził do „owocnego spotkania orędzia chrześcijańskiego z kulturą hellenistyczną”, które „wywarło [...] trwały wpływ na Kościoły Wschodu i Zachodu" ". Zarówno przykład życia, jak i nauczanie doktrynalne tego świętego biskupa i nauczyciela oddziaływały na wszystkie stulecia i również dziś budzą powszechny podziw. Biskupi Rzymu zawsze widzieli w nim żywe źródło mądrości dla Kościoła, a ich zainteresowanie jego nauczaniem nasiliło się w ubiegłym stuleciu. Przed stu laty św. Pius X przy okazji obchodów 1500. rocznicy śmierci św. Jana wezwał Kościół do naśladowania jego cnót ${ }^{2}$. Papież Pius XII ukazał, jak ważny był w dziejach interpretacji Pisma Swiętego wkład św. Jana i jego teorii „zniżania się”, czyli synkatábasis. Według tej teorii Chryzostoma ,słowa Boga, wyrażone w języku ludzkim, stały się podobne do słów ludzkich"3. Sobór Watykański II włączył to spostrzeżenie do Konstytucji dogmatycznej o Objawieniu Bożym Dei verbum ${ }^{4}$. Bł. Jan XXIII zwrócił uwagę na dogłębne zrozumienie przez Chryzostoma wewnętrznej więzi między litur-

"Litterae Apostolicae occasione XVI exeunte saeculo ab obitu Sancti Joannis Chrysostomi, AAS 99 (2007) 1030-1041; Insegnamenti di Benedetto XVI, $3 / 2$ (2007) 111-123; thum. pol. przedruk: OsRomPol 29 (2008) nr 1, 30-35; redakcyjnie oprac. S. Longosz.

${ }^{1}$ Por. Benedictus XVI, Homilia inter Divinam S. Joannis Chrysostomi Liturgiam in Patriarchali Ecclesia S. Georgii ,, al Fanar” (29 XI 2006), Insegnamenti 2/2 (2006) 719, OsRomPol 28 (2007) nr 2, 26.

${ }^{2}$ Por. Pius X, Epistula Venerabili Vincentio S.R.E. Card. Vannutelli (22 VI 1907), ASS 40 (1907) 453-455.

${ }^{3}$ Pius XII, Litterae Encyclicae „,Divino afflante Spiritu” (30 IX 1943): AAS 35 (1943) 316.

${ }^{4}$ Por. Concilium Vaticanum II, Dei Verbum (18 XI 1965); Paulus VI, Sermo ad Italicos Sacrarum Scripturarum Professores occasione XXII Hebdomadae Biblicae Nationalis (29 IX 1972). 
gią Eucharystii i troską o Kościół powszechny5. Sługa Boży Paweł VI wskazywał na ,subtelny i nacechowany żywą wiarą sposób mówienia o tajemnicy Eucharystii" 6 . Pragnę przypomnieć wydarzenie, jakim było uroczyste przekazanie przez mojego umiłowanego poprzednika sługę Bożego Jana Pawła II w listopadzie 2004 r. cennych relikwii świętych Jana Chryzostoma i Grzegorza z Nazjanzu Ekumenicznemu Patriarchatowi Konstantynopola. Papież powiedział wówczas, że gest ten naprawdę stanowi dla Kościoła katolickiego i dla Kościołów prawosławnych „szczęśliwą okazję, by oczyścić naszą zranioną pamięć, umocnić nasze dążenie do pojednania"' . Ja sam, podczas podróży apostolskiej do Turcji, właśnie w katedrze Patriarchatu Konstantynopola, miałem sposobność przypomnieć „wielkich świętych i pasterzy, którzy czuwali nad Stolicą w Konstantynopolu - wśród nich św. Grzegorza z Nazjanzu i św. Jana Chryzostoma, których także Zachód czci jako Doktorów Kościoła. [...] Ci święci są naszymi godnymi orędownikami przed obliczem Boga"8. Cieszę się zatem, że przy okazji 1600. rocznicy jego śmierci mogę przypomnieć tę świetlaną postać jako budujący przykład dla całego Kościoła powszechnego.

2. Życie i posługa św. Jana. Św. Jan Chryzostom urodził się w Antiochii w Syrii w poł. IV wieku. Zgodnie z panującym wówczas zwyczajem kształcił się w zakresie sztuk wyzwolonych i wykazał się szczególnym talentem w sztuce wymowy. W okresie studiów, kiedy był jeszcze młody, poprosił o chrzest; na zaproszenie miejscowego biskupa Melecjusza pełnił posługę lektora tamtejszego Kościoła lokalnego 9 . W tamtej epoce wiernych napawał niepokojem problem, jakim było znalezienie odpowiedniego sposobu, by wyrazić bóstwo Chrystusa. Jan należał do prawowiernych chrześcijan, którzy zgodnie z Powszechnym Soborem Nicejskim wyznawali pełne bóstwo Chrystusa, choć z tego powodu ani on, ani inni chrześcijanie nie spotykali się w Antiochii z przychylnością ze strony władzy cesarskiej ${ }^{10}$. Po przyjęciu chrztu obrał życie ascety. Pod wpływem swego nauczyciela Diodora z Tarsu postanowił, że za-

${ }^{5}$ Por. Joannes XXIII, Litterae Encyclicae „Princeps pastorum” 2 (28 XI 1959), AAS 51 (1959) 846-847.

${ }^{6}$ Paulus VI, Litterae Encyclicae „Mysterium fidei” 17 (3 IX 1965), AAS 57 (1965) 756; por. Benedictus XVI, Sermo in „Angelus” (Castel Gandolfo, 18 IX 2005), Insegnamenti 1 (2005) 554; Exhortatio Apostolica ,, Sacramentum caritatis” 13 (22 II 2007), Insegnamenti 3/1 (2007) 303.

${ }^{7}$ Joannes Paulus II, Epistula ad patriarcham oecumenicum Bartholomaeum I (27 XI 2004); por. S. Longosz, Przekazanie relikwii św. Grzegorza z Nazjanzu I św. Jana Chryzostoma Kościołowi Wschodniemu (Rzym, 27 XI 2004), VoxP 24 (2004) t. 46-47, 859-865..

${ }^{8}$ Benedictus XVI, Homilia inter Divinam S. Joannis Chrysostomi Liturgiam in Patriarchali Ecclesia S. Georgii , al Fanar” (29 XI 2006), Insegnamenti 2/2 (2006) 719.

${ }^{9}$ Por. Joannes Chrysostomus, De sacerdotio I 1-3, SCh 272, 60-76, thum. W. Kania, BOK 1 , 43-47; Palladius, Dialogus de vita Joannis Chrysostomi 5, SCh 341, 104-110.

${ }^{10}$ Por. Theodoretus, Historia religiosa II 18; VIII 5-8, SCh 234, 226-228; 382-392, thum. K. Augustyniak, ŹM 7, 96-97, 150-154. 
chowa celibat przez całe życie, poświęcił się modlitwie, zachowywał surowe posty i zgłębiał Pismo Święte ${ }^{11}$. Opuścił Antiochię i przez sześć lat prowadził życie ascetyczne na pustyni w Syrii, gdzie zaczął pisać traktaty o życiu duchowym ${ }^{12}$. Następnie powrócił do Antiochii, gdzie znów pełnił w Kościele posługę lektora, a potem przez pięć lat diakona. W 386 r. przyjął święcenia kapłańskie od Flawiusza, biskupa Antiochii, i od tej chwili służył już nie tylko modlitwą i pisarstwem, ale również głoszeniem słowa Bożego ${ }^{13}$.

Przez dwanaście lat, w czasie których posługiwał jako kapłan w Kościele antiocheńskim, Jan wielce się wyróżnił umiejętnością wyjaśniania Pisma Świętego w sposób przystępny dla wiernych. Swoimi kazaniami z wielkim zapałem, budząc w słuchaczach poczucie tożsamości chrześcijańskiej, starał się umacniać jedność Kościoła, któremu w tamtym momencie historycznym zagrażały niebezpieczeństwa zarówno wewnętrzne, jak i zewnętrzne. Słusznie sądził, że jedność chrześcijan zależy przede wszystkim od prawidłowego rozumienia głównych tajemnic wiary Kościoła: Trójcy Przenajświętszej i wcielenia Słowa Bożego. Jan dobrze wiedział, jak trudne są to tajemnice, i dlatego dokładał wielkich starań, aby nauczanie Kościoła uprzystępnić prostym członkom swojej wspólnoty, najpierw w Antiochii, a później w Konstantynopolu ${ }^{14}$. Dialogował też z osobami nastawionymi krytycznie, okazując im więcej cierpliwości niźli surowości, bo wierzył, że w zwalczaniu błędów teologicznych „nic nie jest tak skuteczne, jak umiar i uprzejmość"

Dzięki solidnej wierze oraz zdolnościom kaznodziejskim Jan potrafił zaprowadzić zgodę wśród Antiocheńczyków, kiedy na początku jego kapłańskiej posługi cesarz zwiększył podatki w mieście, co wywołało zamieszki, w czasie których doszło do zburzenia kilku należących do państwa budowli. Po tych zamieszkach z obawy przed gniewem cesarza ludzie schronili się w kościele i prosili Jana o słowa chrześcijańskiej nadziei i pocieszenia: „Jeśli nie my was pocieszymy, to gdzie indziej będziecie mogli znaleźć pocieszenie?"16. W swych kazaniach wygłoszonych tamtego roku podczas Wielkiego Postu Jan omówił po kolei wydarzenia, które doprowadziły do rozruchów, i przypomniał swym słuchaczom, co powinno wyróżniać obywatelską postawę chrześcijan ${ }^{17}$,

${ }^{11}$ Por. Joannes Chrysostomus, Laus Diodori episcopi 1-4, PG 52, 761-766; Socrates, HE VI 3, GCS 1, 313-315, tłum. S. Kazikowski: Sokrates Scholastyk, Historia Kościoła, Warszawa 1972, 396-398; Sozomenus, HE VIII 2, GCS 50, 350-351, tłum. S. Kazikowski: Hermiasz Sozomen, Historia Kościoła, Warszawa 1989, 521-525.

${ }^{12}$ Por. Palladius, Dialogus de vita Joannis Chrysostomi 5, SCh 341, 108-110.

${ }^{13}$ Por. tamże, SCh 341, 110-112.

${ }^{14}$ Por. Joannes Chrysostomus, De incomprehensibili Dei natura, SCh 28bis, 93-322; In illud: ,,Pater meus usque modo operator”, PG 63, 511-516; In illud: „Filius ex se nihil facit”, PG 56, 247-256.

${ }^{15}$ Joannes Chrysostomus, De incomprehensibili Dei natura 1, 352-353, SCh 28 bis, 132.

${ }^{16}$ Johannes Chrysostomus, Ad populum Antiochenum 6, 1, PG 49, 81.

${ }_{17}$ Por. tamże 2-21, PG 49, 33-222; Ad illuminandos catecheses 2, PG 49, 231-240, thum. W. Kania, w: Sakramenty wiary, Kraków 1970, 153-160. 
a w szczególności odrzucenie przemocy jako narzędzia przemian politycznych i społecznych ${ }^{18}$. W tym kontekście napominał bogatych chrześcijan, by okazywali miłość ubogim, by stworzyć bardziej sprawiedliwe społeczeństwo, a jednocześnie zalecał, by bardziej wykształceni zgodzili się być nauczycielami i by wszyscy chrześcijanie gromadzili się w kościołach i tam uczyli jedni drugich brzemiona nosić ${ }^{19}$. Potrafił również dodawać otuchy swoim słuchaczom, ożywiając w nich nadzieję i zachęcając, by pokładali ufność w Bogu i liczyli zarówno na Jego pomoc w sprawach doczesnych, jak i na wieczne zbawienie ${ }^{20}$, bo „ucisk wyrabia wytrwałość, a wytrwałość wypróbowaną cnotę, wypróbowana zaś cnota-nadzieję" (Rz 5, 3-4) ${ }^{21}$.

Po dwunastu latach posługi w Kościele antiocheńskim, w którym był kapłanem i kaznodzieją, w 398 r. Jan został konsekrowany na biskupa Konstantynopola, gdzie pozostał przez pięć i pół roku. Jako biskup zajął się reformą duchowieństwa i zachęcał kapłanów, zarówno słowem, jak i własnym przykładem, by żyli zgodnie z Ewangelią ${ }^{22}$. Wspierał żyjących w tym mieście mnichów i troszczył się o ich potrzeby materialne, ale starał się zreformować również ich życie, podkreślając, że ich celem jest wyłączne poświęcenie się modlitwie i życiu w odosobnieniu ${ }^{23}$. Skrupulatnie unikał wszelkiego zbytku i pomimo że był biskupem stolicy cesarstwa, prowadził skromne życie i bardzo hojnie rozdawał jałmużnę ubogim. W każdą niedzielę i w święta Jan głosił kazania. Bardzo uważał, aby oklaski, które często otrzymywał za kazania, nie pozbawiły wyrazistości Ewangelii, którą głosił. Dlatego też żalił się niekiedy, że zbyt często zgromadzenie, które oklaskiwało jego homilie, lekceważyło zawarte w nich wezwania do prawdziwie chrześcijańskiego życia ${ }^{24}$.

Niestrudzenie piętnował kontrasty między ekstrawaganckim marnotrawstwem bogatych mieszkańców miasta i nędzą ubogich, a zarazem sugerował bogatym, by w swoich domach udzielali schronienia bezdomnym ${ }^{25}$. W ubogim widział Chrystusa i do tego samego zachęcał swych słuchaczy, zaznaczając, że powinno to dyktować odpowiednie postępowanie ${ }^{26}$. Tak usilnie bronił ubogich

\footnotetext{
${ }^{18}$ Por. Joannes Chrysostomus, Ad populum Antiochenum 2, 1-3, PG 49, 33-38.

${ }^{19}$ Por. tamże 2, 5; 12, 2; 17, 2, PG 49, 40, 129, 180.

${ }^{20}$ Por. tamże 3,$2 ; 16,5$, PG 49, 49-50, 168-169.

${ }^{21}$ Por. tamże 4, 1, PG 49, 62.

${ }^{22}$ Por. Socrates, HE VI 4, GCS 1, 315-316, tłum. S. Kazikowski, s. 398-399; Sozomenus, HE VIII 3, GCS 50, 352-353, tłum. S. Kazikowski, s. 525-527; Palladius, Dialogus de vita Joannis Chrysostomi 5, SCh 341, 112.

${ }^{23}$ Por. Joannes Chrysostomus, De Lazaro 3, 1, PG 48, 932.

${ }^{24}$ Por. Joannes Chrysostomus, In illud: „Pater meus usque modo operator”, PG 63, 511-516; In Acta apostolorum hom. 30, 4, PG 60, 226-228; Contra ludos et theatra, PG 56, 263-270, thum. W. Kania, PSP 8, 175-181.

${ }^{25}$ Por. Joannes Chrysostomus, In Acta apostolorum hom. 35, 5; 45, 3-4, PG 60, 252, 318-319; Palladius, Dialogus de vita Joannis Chrysostomi 5, SCh 341, 124.

${ }^{26}$ Por. Joannes Chrysostomus, In epistulam ad Colossenses hom. 1, 4, PG 62, 304-305.
} 
i piętnował zbyt bogatych, że wzbudzał oburzenie i wrogość niektórych bogaczy i sprawujących władzę polityczną w mieście ${ }^{27}$.

Wśród biskupów swojej epoki Jan wyróżniał się zapałem misyjnym; rozsyłał misjonarzy, aby głosili Ewangelię wśród tych, którzy jej jeszcze nie słyszeli ${ }^{28}$. Budował szpitale, aby otoczyć opieką chorych ${ }^{29}$. W głoszonych w Konstantynopolu kazaniach na temat Listu do Hebrajczyków twierdził, że Kościół powinien udzielać pomocy materialnej wszystkim ubogim, bez względu na ich wiarę: ,ubogi należy do Boga, nawet jeśli jest poganinem czy żydem. Choćby był niewierzący, zasługuje na pomoc"30.

Urząd biskupa stolicy Cesarstwa Wschodniego nakładał na Jana obowiązek pośredniczenia w delikatnych stosunkach między Kościołem i dworem cesarskim. Często spotykał się z wrogością wielu urzędników cesarskich, niekiedy również dlatego, że stanowczo krytykował zbytek, którym się otaczali. Zarazem jako arcybiskup metropolita Konstantynopola znajdował się w trudnej i delikatnej sytuacji, ponieważ musiał negocjować szereg kwestii kościelnych, które dotyczyły innych biskupów i diecezji. Na skutek intryg, które uknuli przeciw niemu wpływowi wrogowie, jakich miał zarówno w Kościele, jak i w cesarstwie, dwukrotnie został skazany przez cesarza na wygnanie. Zmarł 14 września 1600 lat temu w Comana Pontica, w drodze na drugie wygnanie, z dala od swej umiłowanej ,trzody” w Konstantynopolu.

3. Nauczanie św. Jana. Od V wieku cały Kościół chrześcijański, wschodni i zachodni, otaczał czcią Chryzostoma ze względu na jego odważne świadectwo w obronie wiary Kościoła i wielkoduszne poświęcenie, z jakim pełnił pasterską posługę. Swym nauczaniem doktrynalnym i kaznodziejstwem, jak również troską o liturgię szybko zasłużył sobie na tytuł Ojca i Doktora Kościoła. Sławę, jaką cieszył się jako kaznodzieja, utrwalił również nadany mu, już w VI wieku, przydomek Złotoustego, po grecku Chrysostomos. Tak pisał o nim św. Augustyn: „Popatrz, Julianie, na jakie zebranie cię wprowadziłem. Tu zasiada Ambroży z Mediolanu, [...] Jan z Konstantynopola [...]. Mamy tu Bazylego [...] i reszta mężów, których jednomyślność powinna ciebie poruszyć [...]. W Kościele katolickim zajaśnieli zdrową nauką. Uzbrojeni i przepasani zbroją, prowadzili oni zacięte walki z heretykami, a spracowani na swym urzędzie, zasnęli w Panu [...] oto wprowadziłem ciebie na zebranie świętych, które nie jest zgromadzeniem ludu. Tam znajdują się nie tylko synowie, ale i Ojcowie Kościoła"31.

${ }^{27}$ Por. Joannes Chrysostomus, Cum Saturninus et Aurelianus 2, PG 52, 415-416.

${ }^{28}$ Por. Theodoretus, Historia religiosa 5, 31, GCS 44, 330-331; Joannes Chrysostomus, Epistulae ad Olimpiadem 9, 5, SCh 13bis, 236-238.

${ }^{29}$ Por. Palladius, Dialogus de vita Joannis Chrysostomi 5, SCh 341, 122.

${ }^{30}$ Joannes Chrysostomus, In epistulam ad Hebraeos hom. 10, 4, PG 63, 88.

${ }_{31}$ Augustinus, Contra Julianum I 7, 30-31, PL 44, 661-662, thum. W. Eborowicz, PSP 19/1, 112-113. 
Na szczególną uwagę zasługują również usilne starania Jana Chryzostoma, by doprowadzić do pojednania i pełnej komunii między chrześcijanami Wschodu i Zachodu. W szczególności decydujący był jego wkład w zniesienie schizmy między Antiochią a Rzymem i innymi Kościołami zachodnimi. Kiedy Jan został konsekrowany na biskupa Konstantynopola, wysłał do Rzymu delegację do papieża Syrycjusza. Aby zapewnić powodzenie tej misji, której celem było położenie kresu schizmie, nawiązał współpracę z biskupem Aleksandrii w Egipcie. Papież Syrycjusz odniósł się do dyplomatycznej inicjatywy Jana przychylnie i tak w sposób pokojowy doszło do zniesienia schizmy i została przywrócona pełna jedność między Kościołami.

Później, już pod koniec życia, kiedy Jan powrócił do Konstantynopola z pierwszego wygnania, napisał list do papieża Innocentego, a także do biskupów Weneriusza z Mediolanu i Chromacjusza z Akwilei, prosząc ich o pomoc w przywróceniu ładu w Kościele konstantynopolitańskim, podzielonym na skutek niesprawiedliwości, jakie go spotkały. Jan oczekiwał od papieża Innocentego i innych biskupów zachodnich interwencji, która „świadczyłaby o przychylności - jak napisał - nie tylko dla nas, ale dla całego Kościoła"32. Bowiem według Chryzostoma, kiedy część Kościoła zostaje zraniona, cierpi również cały Kościół. Papież Innocenty bronił Jana, kierując kilka listów do biskupów Wschodu ${ }^{33}$. Potwierdzał w nich pełną komunię z Janem, nie przyjmując do wiadomości zdjęcia go z urzędu, które uważał za bezpraw$\mathrm{n}^{34}$. Pisał też do Jana, aby go pocieszyćc ${ }^{35}$, oraz do duchowieństwa i wiernych w Konstantynopolu, aby wyrazić pełne poparcie dla ich prawowitego biskupa: „Jan, wasz biskup, cierpiał niesłusznie”, stwierdzał papież ${ }^{36}$. Ponadto zwołał synod biskupów włoskich i wschodnich, aby oddać sprawiedliwość prześladowanemu biskupowi ${ }^{37}$. Z poparciem cesarza zachodniego, papież wysłał do cesarza wschodniego w Konstantynopolu delegację biskupów zachodnich i wschodnich, aby bronić Jana i prosić, by powszechny sobór biskupów oddał mu sprawiedliwość ${ }^{38}$. Kiedy tuż przed jego śmiercią na wygnaniu usiłowania te spełzły na niczym, Jan napisał list do papieża Innocentego, aby podziękować mu za „wielkie pocieszenie”, jakim było dla niego wielkoduszne

${ }^{32}$ Joannes Chrysostomus, Epistula ad Innocentium papam 1, SCh 342, 93; por. tłum. W. Kania, PSP 13, 240 lub BOK 19, 196.

${ }^{33}$ Por. Palladius, Dialogus de vita Joannis Chrysostomi 3, SCh 341, 64-68; Innocentius I papa, Epistula 5, PL 20, 493-495.

${ }^{34}$ Por. Palladius, Dialogus de vita Joannis Chrysostomi 3, SCh 341, 66-68.

${ }^{35}$ Por. Sozomenus, HE VIII 26, GCS 50, 384-385, tłum. S. Kazikowski, s. 574-575 (List Innocentego do Jana).

${ }^{36}$ Tamże VIII 26, 12, GCS 50, 386, thum. S. Kazikowski, s. 575-577 (List Innocentego do duchownych i wiernych Konstantynopola).

${ }^{37}$ Por. Palladius, Dialogus de vita Joannis Chrysostomi 4, SCh 341, 84.

${ }^{38}$ Por. tamże 3-4, SCh 341, 80-86. 
wsparcie, które otrzymał ${ }^{39}$. W swym liście z wygnania pisał, że choć dzieli ich wielka odległość, „każdego dnia trwa z nim w komunii”, po czym dodał: „W życzliwości, jaką nam okazałeś, i gorliwości przewyższyłeś nawet najbardziej kochającego z ojców”. Błagał go jednak, aby nadal zabiegał o sprawiedliwość dla niego i Kościoła w Konstantynopolu, bo „teraz bitwę, która cię czeka, trzeba stoczyć dla dobra niemal całego świata, Kościoła upokorzonego do cna, ludu rozproszonego, duchowieństwa znieważonego, biskupów zesłanych na wygnanie, dawnych praw pogwałconych". Jan pisał również do innych biskupów zachodnich, aby podziękować im za wsparcie ${ }^{40}$; byli wśród nich we Włoszech: Chromacjusz z Akwilei ${ }^{41}$, Weneriusz z Mediolanu ${ }^{42}$ oraz Gaudenty z Brescii ${ }^{43}$.

Zarówno w Antiochii, jak i w Konstantynopolu Jan z wielkim zaangażowaniem mówił o jedności Kościoła rozproszonego na całym świecie. „Wierni w Rzymie - pisał - uważają, że wierni w Indiach są członkami ich własnego ciała”"44; podkreślał też, że w Kościele nie ma miejsca na podziały. „Kościół głosił - istnieje nie po to, aby dzielili się ci, którzy się zjednoczyli, lecz po to, by mogli się zjednoczyć ci, którzy się podzielili" ${ }^{45}$. Potwierdzenie tej jedności znajdował w Piśmie Świętym. W kazaniu na temat Pierwszego Listu św. Pawła do Koryntian, przypominał swym słuchaczom, że „Paweł mówi o Kościele jako «Kościele Bożym» (por. 1Kor 1, 2) i pokazuje, że musi on być zjednoczony, ponieważ jeśli jest „Boży», jest jednością, i to nie tylko w Koryncie, ale również w świecie; imię Kościoła nie oznacza bowiem rozdziału, lecz jedność i zgodę"46.

Dla Jana jedność Kościoła opiera się na Chrystusie, Słowie Bożym, które poprzez wcielenie zjednoczyło się z Kościołem jak głowa z ciałem ${ }^{47}$ : „Gdzie jest głowa, tam również jest i ciało”, i dlatego „,nie ma rozdziału między głową i ciałem"48. Jan zrozumiał, że we wcieleniu Słowo Boże nie tylko stało się człowiekiem, ale także zjednoczyło się z nami, czyniąc z nas swoje ciało: „Ponieważ nie wystarczało Mu, że stał się człowiekiem, został przebity i zabity, jednoczy się z nami nie tylko przez wiarę, ale również przez to, że czyni nas

${ }^{39}$ Por. Joannes Chrysostomus, Epistula ad Innocentium papam 2, PG 52, 535-536, thum. W. Kania, PSP 13, 245-246.

${ }^{40}$ Por. Joannes Chrysostomus, Epistulae 157-161, PG 52,703-706.

${ }^{41}$ Por. Joannes Chrysostomus, Epistula 155 (ad Chromatium Aquileiae episcopum), PG 52, 702-703.

${ }^{42}$ Por. Joannes Chrysostomus, Epistula 182 (ad Venericum Mediolanensium), PG 52, 714-715.

${ }^{43}$ Por. Joannes Chrysostomus, Epistula 184 PG 52, 715-716.

${ }^{44}$ Joannes Chrysostomus, In Joannem hom. 65, 1, PG 59, 361-362.

${ }^{45}$ Joannes Chrysostomus, In epistulam I ad Corinthios hom. 27, 3, PG 61, 228.

${ }^{46}$ Joannes Chrysostomus, In epistulam I ad Corinthios hom. 1, 1, PG 61, 13.

${ }^{47}$ Por. tamże 30, 1, PG 61, 249-251; In epistulam ad Colossenses hom. 3, 2-3, PG 62, 320; In epistulam ad Ephesios hom. 3, 2, PG 62, 26.

${ }^{48}$ Joannes Chrysostomus, In epistulam ad Ephesios hom. 3, 2, PG 62, 26. 
swoim ciałem”49. Komentując fragment z Listu św. Pawła do Efezjan: „,wszystko poddał pod Jego stopy, a Jego samego ustanowił nade wszystko Głową dla Kościoła, który jest Jego Ciałem, Pełnią Tego, który napełnia wszystko na wszelki sposób” (Ef 1, 22-23), Jan wyjaśnia, że ,jest to jak z głową, której dopełnieniem jest ciało, bo ciało tworzą różne składające się na nie części. Wszyscy zatem tworzą Jego ciało. I dlatego głowa jest „cała” i ciało osiąga doskonałość, kiedy my wszyscy jesteśmy razem i trwamy w jedności" ${ }^{50}$. Na koniec Jan stwierdza, że Chrystus wszystkie członki swego Kościoła jednoczy z samym sobą i między sobą. Nasza wiara w Chrystusa wymaga, abyśmy dążyli do rzeczywistej, sakramentalnej jedności członków Kościoła, która położy kres wszelkim podziałom.

Według Chryzostoma, „o jedności Kościoła, która urzeczywistnia się w Chrystusie, daje się świadectwo w sposób całkiem wyjątkowy w czasie Eucharystii”. Ze względu na zakres i głębię jego doktryny o Najświętszym Sakramencie nazywano go również „doktorem eucharystycznym" ${ }^{2}$. Nauczał on, że sakramentalna jedność Eucharystii stanowi podstawę jedności kościelnej w Chrystusie i przez Chrystusa. „Oczywiście, wiele rzeczy nas łączy i jednoczy. Stół został przygotowany dla wszystkich [...] wszystkim podano ten sam napój, a raczej nie tylko ten sam napój, ale również ten sam kielich. Nasz Ojciec, chcąc w nas rozbudzić czułe uczucia, przykazał również, abyśmy pili z jednego kielicha, co jest znamieniem wielkiej miłości" ${ }^{52}$. Komentując słowa z Pierwszego Listu św. Pawła do Koryntian: „Chleb, który łamiemy, czyż nie jest udziałem w Ciele Chrystusa?” (1Kor 10, 16), Jan mówi: dla Apostoła zatem „tak jak to ciało jest zjednoczone z Chrystusem, tak też i my jesteśmy z Nim zjednoczeni poprzez ten chleb"53. Jeszcze wyraźniej mówi o tym w świetle dalszych słów Apostoła: „Ponieważ my, choć liczni, jesteśmy jednym chlebem, jednym ciałem” (1Kor 10, 17), wyjaśniając: „Czym jest chleb? Ciałem Chrystusa. A czym stają się ci, którzy go spożywają? Ciałem Chrystusa; nie wieloma ciałami, ale jednym ciałem. Tak jak chleb, na który składają się liczne ziarna, stanowi jedną całość [...] tak też i my jesteśmy zjednoczeni czy to między sobą, czy to z Chrystusem. [...] A zatem jeśli spożywamy ten sam chleb i stajemy się tym samym, dlaczego nie okazujemy również tej samej miłości, abyśmy również pod tym względem stanowili jedno?" 54 .

\footnotetext{
${ }^{49}$ Joannes Chrysostomus, In Matthaeum hom. 82, 5, PG 58, 743; por. thum. J. Krystyniacki, ŹMT 23, 461-462.

${ }^{50}$ Joannes Chrysostomus, In epistulam ad Ephesios hom. 3, 2, PG 62, 26; por. tamże 20, 4 PG 62, 140-141.

${ }^{51}$ Por. Benedictus XVI, Sermo in „Angelus” (Castel Gandolfo, 18 IX 2005), Insegnamenti 1 (2005) 555 .

52 Joannes Chrysostomus, In Matthaeum hom. 32, 7, PG 57, 386.

${ }^{53}$ Joannes Chrysostomus, In epistulam I ad Corinthios hom. 24, 2, PG 61, 200; por. In Joannem hom. 46, 3, PG 63, 260-261; In epistulam ad Ephesios hom. 3, 4, PG 62, 28-29.

${ }^{54}$ Joannes Chrysostomus, In epistulam I ad Corinthios hom. 24, 2, PG 61, 200.
} 
Wiara Chryzostoma w tajemnicę miłości, która wiąże wierzących z Chrystusem i między sobą, była źródłem jego głębokiej czci dla Eucharystii, co w sposób szczególny wyrażało się w sprawowaniu boskiej liturgii. Jedna z najbogatszych wersji liturgii wschodniej nosi właśnie jego imię: „Boska liturgia św. Jana Chryzostoma". Jan rozumiał, że boska liturgia przenosi duchowo człowieka wierzącego między życie ziemskie i rzeczywistość nieba, obiecaną nam przez Pana. Tak o swej czci i bojaźni w czasie sprawowania świętych misteriów mówił Bazylemu Wielkiemu: „Kiedy widzisz Pana złożonego w ofierze, leżącego na ołtarzu, i kapłana, który stojąc, modli się nad ofiarą [...] czy możesz jeszcze myśleć, że jesteś wśród ludzi, że stoisz na ziemi? Czyż nie zostajesz raczej przeniesiony nagle do nieba?” Święte obrzędy, pisze Jan, „nie tylko cieszą oczy pięknem, ale ich niezwykłość polega na tym, że budzą bojaźń i cześć. W nich kapłan stojąc [...] przyzywa Ducha Świętego, modli się długo, aby łaska, która zstępuje na ofiarę, mogła oświecić umysły wszystkich, którzy się tam znajdują, i sprawić, by jaśniały one bardziej niźli srebro oczyszczone w ogniu. Któż może pogardzać tym świętym misterium?"55.

Chryzostom snuje głębokie refleksje o skutkach komunii sakramentalnej w wierzących: „Krew Chrystusa odnawia w nas obraz naszego Króla, tworzy niewysłowione piękno i nie pozwala na zniszczenie szlachetnej godności naszych dusz, ale nieustannie je poi i karmi" ${ }^{56}$. Dlatego też Jan często i usilnie zachęca wiernych, aby w godny sposób przystępowali do ołtarza Pańskiego: „nie lekkomyślnie [...] nie z przyzwyczajenia czy jakby chodziło o jakąś formalność”, ale ,szczerze i z czystą duszą " "57. Niestrudzenie powtarza, że przystępowaniu do komunii św. musi towarzyszyć żal za grzechy i wdzięczność za ofiarę złożoną przez Chrystusa dla naszego zbawienia. Dlatego poucza wiernych, aby w pełni i pobożnie uczestniczyli w obrzędach boskiej liturgii i tak samo przyjmowali komunię św.: „Nie pozwólcie, prosimy, abyście zabijali nas brakiem należytego szacunku, ale przystępujcie do Niego pobożnie i w czystości, a kiedy widzicie Go przed sobą, mówcie do siebie: „Ze względu na to ciało już nie jestem ziemią i popiołem, nie jestem już więźniem, ale wolnym człowiekiem; ze względu na nie mam nadzieję na raj, na to, że otrzymam dobra, dziedzictwo aniołów i że będę rozmawiał z Chrystusem»" $" 58$.

Oczywiście, z kontemplacji Misterium wyciąga również wnioski moralne, które przekazuje swym słuchaczom: przypomina im, że komunia z Ciałem

${ }^{55}$ Joannes Chrysostomus, De sacerdotio 3, 4, SCh 272, 142-146, por. thum. W. Kania, BOK 1, 73; zob. Benedictus XVI, Adhortatio Apostolica „Sacramentum caritatis” 13 (22 II 2007), Insegnamenti 3/1 (2007) 303, thum. pol. wyd. Pallottinum, Poznań 2007, 18.

${ }^{56}$ Joannes Chrysostomus, In Joannem hom. 46, 3, PG 63, 261.

${ }^{57}$ Joannes Chrysostomus, In epistulam ad Ephesios hom. 3, 4, PG 62, 28; In epistulam I ad Corinthios hom. 24, PG 61, 197-206; tamże 27, 4, PG 61, 229-230; In epistulam I ad Timotheum hom. 15, 4, PG 62, 583-586; In Matthaeum hom. 82, 6, PG 58, 744-746, por. thum. J. Krystyniacki, ŹMT 23, 462-463.

${ }^{58}$ Joannes Chrysostomus, In epistulam I ad Corinthios hom. 24, 4, PG 61, 203. 
i Krwią Chrystusa zobowiązuje do udzielania pomocy materialnej ubogim i chorym, którzy żyją wśród nich ${ }^{59}$. Stół Pański jest miejscem, w którym wierzący rozpoznają i przyjmują ubogiego i potrzebującego, którego wcześniej być może ignorowali ${ }^{60}$. Zaleca on wierzącym wszystkich czasów, aby sięgając wzrokiem poza ołtarz, na którym składana jest eucharystyczna ofiara, widzieli Chrystusa w osobach ubogich i pamiętali, że dzięki pomocy udzielonej potrzebującym mogą złożyć na Chrystusowym ołtarzu miłą Bogu ofiarę ${ }^{61}$.

4. Zakończenie. Za każdym razem, gdy spotykamy tych naszych Ojców - napisał papież Jan Paweł II o innym wielkim Ojcu i Doktorze św. Bazylim - ,jesteśmy pokrzepieni w wierze i umocnieni w nadziei" ${ }^{62}$. 1600-lecie śmierci św. Jana Chryzostoma stanowi sprzyjającą okazję do wzmożenia badań nad nim, recepcji jego nauczania i szerzenia nabożeństwa do tego świętego. W różnych inicjatywach oraz uroczystościach, które z okazji tej 1600. rocznicy są organizowane, uczestniczę duchowo z wdzięcznością i przychylnością. Pragnę również dać wyraz memu żywemu pragnieniu, aby Ojcowie Kościoła, w których „głosie rozbrzmiewa niezmienna Tradycja chrześcijańska" ${ }^{63}$, stawali się coraz bardziej pewnym punktem odniesienia dla wszystkich teologów Kościoła. Powracać do nich oznacza sięgać do źródeł doświadczenia chrześcijańskiego, aby czerpać z nich świeżość i prawdziwość. Czegóż więcej mógłbym życzyć teologom niż nowego zapału w zgłębianiu mądrościowego dziedzictwa świętych Ojców? Wzbogaci to z pewnością również ich refleksje na temat współczesnych zagadnień.

Pragnę zakończyć ten dokument ostatnim słowem wielkiego Doktora, w którym prosił on swoich wiernych - i oczywiście również nas - aby myśleli o wartościach odwiecznych: „Jak długo jeszcze będziemy przybici do rzeczy teraźniejszych? Ile czasu jeszcze nam potrzeba, abyśmy się ocknęli? Jak długo jeszcze będziemy zaniedbywać nasze zbawienie? Pozwólcie przypomnieć to, czego w uznaniu Chrystusa jesteśmy godni, pozwólcie, że Mu podziękujemy, uwielbimy Go, nie tylko naszą wiarą, ale również naszymi konkretnymi dziełami, abyśmy mogli osiągnąć dobra przyszłe przez łaskę i pełną miłości

${ }^{59}$ Por. Joannes Chrysostomus, In epistulam I ad Corinthios hom. 27, 5, PG 61, 230-231, In Genesim hom. 5, 3, PG 54, 602-603.

${ }^{60}$ Por. Joannes Chrysostomus, In epistulam I ad Corinthios hom. 27, 5, PG 61, 230.

${ }^{61}$ Por. Joannes Chrysostomus, In epistulam II ad Corinthios hom. 20, 3, PG 61, 540; In epistulam ad Romanos hom. 21, 2-4, PG 60, 603-607, thum. T. Sinko: Św. Jan Chryzostom, Homilie na List św. Pawła do Rzymian, I/2, Kraków 1998, 341-348.

${ }^{62}$ Joannes Paulus II, Epistula Apostolica „Patres Ecclesiae” 1 (2 I 1980), AAS 72 (1980) 5, OsRomPol 1 (1980) nr 3, 14.

${ }^{63}$ Benedictus XVI, Discorso durante l'Udienza generale 3 (9 XI 2005), Insegnamenti 1 (2005) 768, OsRomPol 27 (2006) nr 3, 40. 
czułość naszego Pana Jezusa Chrystusa, przez którego i z którym chwała niech będzie Ojcu i Duchowi Świętemu, teraz i na wieki wieków. Amen" ${ }^{64}$.

Wszystkim udzielam mego Błogosławieństwa!

Castel Gandolfo, 10 sierpnia 2007 r., $\mathrm{w}$ trzecim roku pontyfikatu

Benedictus PP XVI

${ }^{64}$ Joannes Chrysostomus, In Joannem hom. 46, 4, PG 63, 262. 
